\title{
Mercury concentrations and distribution in soil, water, mine waste leachates, and air in and around mercury mines in the Big Bend region, Texas, USA
}

\author{
John E. Gray • Peter M. Theodorakos • \\ David L. Fey $\cdot$ David P. Krabbenhoft
}

Received: 4 March 2014/ Accepted: 19 June 2014/Published online: 29 June 2014

(C) The Author(s) 2014. This article is published with open access at Springerlink.com

\begin{abstract}
Samples of soil, water, mine waste leachates, soil gas, and air were collected from areas mined for mercury $(\mathrm{Hg})$ and baseline sites in the Big Bend area, Texas, to evaluate potential $\mathrm{Hg}$ contamination in the region. Soil samples collected within $300 \mathrm{~m}$ of an inactive $\mathrm{Hg}$ mine contained elevated $\mathrm{Hg}$ concentrations $(3.8-11 \mu \mathrm{g} / \mathrm{g})$, which were considerably higher than $\mathrm{Hg}$ in soil collected from baseline sites $(0.03-0.05 \mu \mathrm{g} / \mathrm{g}$ ) distal (as much as $24 \mathrm{~km}$ ) from mines. Only three soil samples collected within $300 \mathrm{~m}$ of the mine exceeded the probable effect concentration for $\mathrm{Hg}$ of $1.06 \mu \mathrm{g} / \mathrm{g}$, above which harmful effects are likely to be observed in sediment-dwelling organisms. Concentrations of $\mathrm{Hg}$ in mine water runoff (7.9-14 ng/L) were generally higher than those found in springs and wells $(0.05-3.1 \mathrm{ng} / \mathrm{L})$, baseline streams (1.1-9.7 ng/L), and sources of drinking water (0.63-9.1 ng/L) collected in the Big Bend region. Concentrations of $\mathrm{Hg}$ in all water samples collected in this study were considerably below the $2,000 \mathrm{ng} / \mathrm{L}$ drinking water $\mathrm{Hg}$ guideline and the $770 \mathrm{ng} / \mathrm{L}$ guideline recommended by the U.S. Environmental Protection Agency (USEPA) to protect aquatic wildlife from
\end{abstract}

J. E. Gray $(\bowtie)$ · P. M. Theodorakos · D. L. Fey

U.S. Geological Survey, MS 973, Federal Center, Denver, CO 80225, USA

e-mail: jgray@usgs.gov

D. P. Krabbenhoft

U.S. Geological Survey, 8505 Research Way, Middleton, WI 53562, USA chronic effects of $\mathrm{Hg}$. Concentrations of $\mathrm{Hg}$ in water leachates obtained from leaching of mine wastes varied widely from $<0.001$ to $760 \mu \mathrm{g}$ of $\mathrm{Hg}$ in leachate/g of sample leached, but only one leachate exceeded the USEPA $\mathrm{Hg}$ industrial soil screening level of $31 \mu \mathrm{g} / \mathrm{g}$. Concentrations of $\mathrm{Hg}$ in soil gas collected at mined sites $\left(690-82,000 \mathrm{ng} / \mathrm{m}^{3}\right)$ were highly elevated compared to soil gas collected from baseline sites $\left(1.2-77 \mathrm{ng} / \mathrm{m}^{3}\right)$. However, air collected from mined areas at a height of $2 \mathrm{~m}$ above the ground surface contained concentrations of $\mathrm{Hg}$ (4.9-64 ng/ $\mathrm{m}^{3}$ ) that were considerably lower than $\mathrm{Hg}$ in soil gas from the mined areas. Although concentrations of $\mathrm{Hg}$ emitted from mine-contaminated soils and mine wastes were elevated, persistent wind in southwest Texas disperses $\mathrm{Hg}$ in the air within a few meters of the ground surface.

Keywords Mercury $\cdot$ Soil $\cdot$ Stream water $\cdot$ Air · Leachates

\section{Introduction}

Contamination of land, water, and air by $\mathrm{Hg}$ has been known as a global issue for many years (WHO 1976; Nriagu and Pacyna 1988; Fitzgerald and Clarkson 1991). Mercury has no biological function in humans and exposure to high $\mathrm{Hg}$ concentrations is a potential hazard (NAS 1978; Eisler 1987; USEPA 1997). All 
forms of $\mathrm{Hg}$ are toxic, but organic $\mathrm{Hg}$ compounds such as methyl- $\mathrm{Hg}\left(\mathrm{CH}_{3} \mathrm{Hg}^{+}\right)$are the most toxic (WHO 1990; Ullrich et al. 2001). Inorganic Hg in land sources is potentially converted to methyl-Hg in aquatic environments by the action of microorganisms, especially in organic-rich sediment (Compeau and Bartha 1985).

Areas previously mined for $\mathrm{Hg}$ are of potential concern as $\mathrm{Hg}$ can be extremely high in mine waste calcine (retorted ore) and runoff sediment, exceeding $1 \%$ by weight in some cases (Gray et al. 2002, 2004). Concentrations of $\mathrm{Hg}$ remain highly elevated in soil, sediment, and water near mined areas many years after the cessation of Hg mining (Gosar et al. 1997; Bailey et al. 2002; Qiu et al. 2005; Gray and Hines 2006; Rimondi et al. 2012). Similarly, $\mathrm{Hg}$ concentrations are highly elevated around mines of the Terlingua district located in and around Big Bend National Park (BBNP) (Gray et al. 2006, 2008). Mining of $\mathrm{Hg}$ in the Big Bend region, Texas, was carried out from 1888 to 1973 and constituted an important $\mathrm{Hg}$ resource in the USA. Production of $\mathrm{Hg}$ exceeded 5,000 $\mathrm{t}$ from mines of the Terlingua district, ranking it as the third largest $\mathrm{Hg}$ district in the USA. Like most $\mathrm{Hg}$ mines worldwide, the dominant $\mathrm{Hg}$ ore in the Terlingua district was cinnabar (hexagonal, $\mathrm{HgS}$ ), but metacinnabar (isometric, $\mathrm{HgS}$ ), elemental $\mathrm{Hg}\left(\mathrm{Hg}_{(\mathrm{L})}^{0}\right)$, and $\mathrm{Hg}$ chlorides such as calomel $\left(\mathrm{Hg}_{2} \mathrm{Cl}_{2}\right)$, and oxychlorides such as terlinguaite $\left(\mathrm{Hg}_{2} \mathrm{ClO}\right)$ and eglestonite $\left(\mathrm{Hg}_{2} \mathrm{Cl}_{2} \mathrm{O}\right)$ were identified at some mines (Ross 1941). A considerable volume of mine waste calcine generated during mining is present at mines in this region (Gray et al. 2006). These calcines contain highly elevated concentrations of $\mathrm{Hg}$, which are available for downstream and downwind transport, leaching, and biogeochemical transformation to methyl-Hg.

The objective of this study was to evaluate potential $\mathrm{Hg}$ contamination of soil, water, and air in the Big Bend region. With the exception of the Mariscal mine, mines of the Terlingua $\mathrm{Hg}$ district are located just outside of the BBNP boundary (Fig. 1). To evaluate potential $\mathrm{Hg}$ contamination in this region, concentrations of $\mathrm{Hg}$ and/or methyl-Hg were measured in (1) soil collected proximal to the Mariscal mine in BBNP, (2) stream water collected proximal and distal from mined areas, (3) water leachates obtained from leaching of mine waste calcine, and (4) soil gas and air collected from mined areas and baseline sites distal from mines.
Study area

The area of study was the Terlingua $\mathrm{Hg}$ district, southwest Texas. Mining of $\mathrm{Hg}$ was carried out in this region between about 1888 and 1973 (Sharp 1980; Avery et al. 1996) and total production of $\mathrm{Hg}$ was $>5,000 \mathrm{t}$, which ranks Terlingua as the third largest $\mathrm{Hg}$ district in the USA. One consequence of $\mathrm{Hg}$ mining is that considerable mine waste is generated during ore processing, which is typically discarded on the mine site, and much of this mine waste contains toxic $\mathrm{Hg}$ compounds. Greater than 2,000,000 $\mathrm{m}^{3}$ of mine waste, calcine remains in the Terlingua district and about $30,000 \mathrm{~m}^{3}$ at the Mariscal mine. This mine waste contains elevated $\mathrm{Hg}$ concentrations due to incomplete $\mathrm{Hg}$ recovery and generation of $\mathrm{Hg}$ byproduct compounds during retorting, some of which are water soluble (Kim et al. 2003; Gray et al. 2010).

The study area is in the Chihuahuan Desert. During fieldwork, the climate was generally hot $\left(26-41{ }^{\circ} \mathrm{C}\right)$, dry, and sunny to partly cloudy. The wind direction is dominantly from the south and southwest in this region. Precipitation in this area averages about $25 \mathrm{~cm} /$ year, occurring principally as storm events. Generally, most precipitation in this region falls from July to September, but this is temporally and spatially variable. Most of the streams and smaller tributaries in the study area are ephemeral, and these streams were sampled during or shortly after storm events. However, the Rio Grande is perennial.

\section{Methods}

Sample collection and preparation

\section{Soil}

Soil samples were collected from 15 sites in the Mariscal mine area, and an additional five samples were collected from baseline sites distal from $\mathrm{Hg}$ mines in the area (Fig. 1, Table 1). The soil samples were collected in amber glass vessels with Teflonlined lids and were frozen until analysis. Soil was collected from the near-surface A-horizon at depths of about $1-5 \mathrm{~cm}$ following the removal of any rock fragments. The sites generally contained low amounts of organic matter, and no O-horizon was present at any of the collection sites. These soil samples contained 


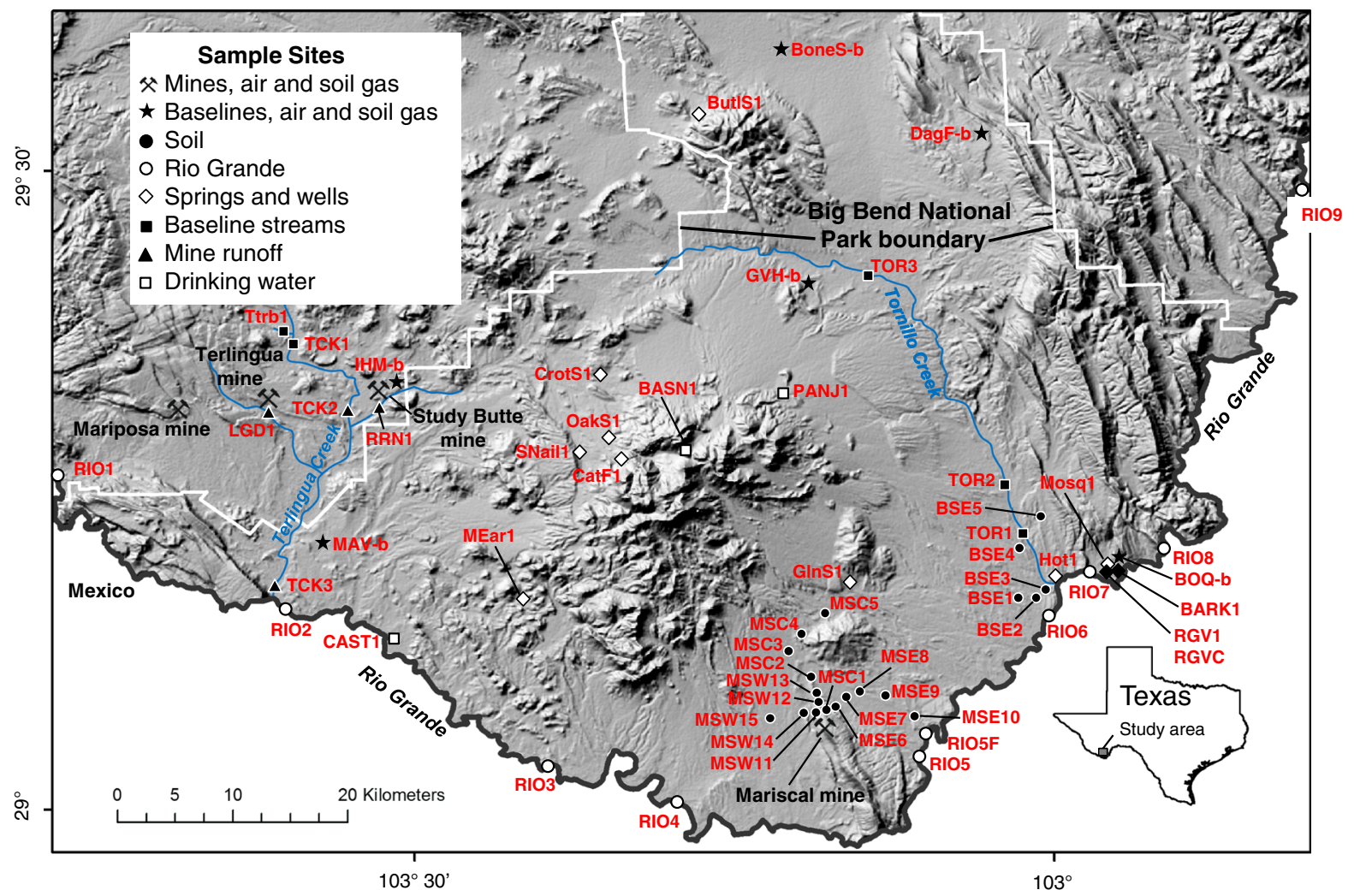

Fig. 1 Study area and location of sample sites

fine-grained material consisting dominantly of fine silt and clay-sized material. Soil collected from the three sites most proximal to the Mariscal mine (Table 1, MSC1, MSE6, and MSW11) contained some finegrained mine waste calcine, which was likely windblown from calcine piles found in this mined area. Prior to geochemical analysis, the soil samples were air-dried at room temperature and then pulverized in a ceramic plate grinder to a grain size of $<150 \mu \mathrm{m}$.

\section{Mine waste calcine}

Samples of mine waste calcine used for the leachate studies were those from an archived collection that were used in a previously published study (Gray et al. 2006). Grab samples of calcine were collected about $25-50 \mathrm{~cm}$ below the waste-pile surface to avoid the highly oxidized, near-surface environment and sieved to $-2 \mathrm{~mm}$ in the field. Calcine is retorted ore that is composed dominantly of rock fragments and minerals such as quartz, feldspar, clay, hematite, and mica.
Calcine also contains some cinnabar that survives retorting as well as elemental $\mathrm{Hg}$ and $\mathrm{Hg}$ minerals such as chlorides and oxychlorides that are formed during retorting, which generally constitute $<1 \%$ of the calcine material (Gray et al. 2010). Calcine samples were frozen, and prior to geochemical analysis, they were air-dried and then pulverized in a ceramic plate grinder to a grain size of $<150 \mu \mathrm{m}$.

\section{Leachates}

Mine waste calcine samples were leached using a modified version of the USEPA synthetic precipitation leaching procedure, Method 1312 (USEPA 1994), to evaluate the capacity of these sample to leach $\mathrm{Hg}$ when exposed to water in a laboratory setting. Following the 1312 Method, $100 \mathrm{~g}$ of sample was leached with $2 \mathrm{~L}$ of deionized water acidified to a $\mathrm{pH}$ of 4.2 , and the samples were then rotated at $28 \mathrm{rpm}$ for $18 \mathrm{~h}$. Our only modification of the 1312 Method was that the leachate was collected as four separate 
Table 1 Geochemical data for soil samples

\begin{tabular}{|c|c|c|c|c|c|}
\hline $\begin{array}{l}\text { Sample } \\
\#\end{array}$ & Location & $\begin{array}{l}\mathrm{Hg} \\
\mu \mathrm{g} / \mathrm{g}\end{array}$ & $\begin{array}{l}\text { Methyl- } \\
\mathrm{Hg} \\
\mathrm{ng} / \mathrm{g}\end{array}$ & $\begin{array}{l}\text { Methyl- } \\
\mathrm{Hg} / \mathrm{Hg} \%\end{array}$ & TOC \% \\
\hline \multicolumn{6}{|c|}{ North traverse } \\
\hline MSC1 & $\begin{array}{l}30 \mathrm{~m} \mathrm{~N} \text { of } \\
\text { Mariscal mine }\end{array}$ & 11 & 0.54 & 0.005 & 0.68 \\
\hline MSC2 & $\begin{array}{l}800 \mathrm{~m} \mathrm{~N} \text { of } \\
\text { Mariscal mine }\end{array}$ & 0.07 & 0.09 & 0.12 & 0.38 \\
\hline MSC3 & $\begin{array}{l}1.5 \mathrm{~km} \mathrm{~N} \text { of } \\
\text { Mariscal mine }\end{array}$ & 0.02 & 0.10 & 0.44 & 0.37 \\
\hline MSC4 & $\begin{array}{l}4.5 \mathrm{~km} \mathrm{~N} \text { of } \\
\text { Mariscal mine }\end{array}$ & 0.03 & 0.16 & 0.61 & 0.30 \\
\hline MSC5 & $\begin{array}{l}6 \mathrm{~km} \mathrm{~N} \text { of } \\
\text { Mariscal mine }\end{array}$ & 0.14 & 0.09 & 0.06 & 0.33 \\
\hline \multicolumn{6}{|c|}{ East traverse } \\
\hline MSE6 & $\begin{array}{l}300 \mathrm{~m} \text { E of } \\
\text { Mariscal mine }\end{array}$ & 3.8 & 0.51 & 0.01 & 0.54 \\
\hline MSE7 & $\begin{array}{l}750 \mathrm{~m} \mathrm{E} \text { of } \\
\text { Mariscal mine }\end{array}$ & 0.81 & 0.15 & 0.02 & 0.47 \\
\hline MSE8 & $\begin{array}{l}2.5 \mathrm{~km} \mathrm{E} \text { of } \\
\text { Mariscal mine }\end{array}$ & 0.04 & 0.05 & 0.13 & 0.30 \\
\hline MSE9 & $\begin{array}{l}5 \mathrm{~km} \mathrm{E} \mathrm{of} \\
\text { Mariscal mine }\end{array}$ & 0.05 & 0.07 & 0.14 & 0.51 \\
\hline MSE10 & $\begin{array}{l}7.5 \mathrm{~km} \mathrm{E} \text { of } \\
\text { Mariscal mine }\end{array}$ & 0.05 & 0.07 & 0.14 & 0.28 \\
\hline \multicolumn{6}{|c|}{ West traverse } \\
\hline MSW11 & $\begin{array}{l}100 \mathrm{~m} \mathrm{~N} \text { of } \\
\text { Mariscal mine }\end{array}$ & 6.2 & 0.43 & 0.007 & 0.82 \\
\hline MSW12 & $\begin{array}{l}400 \mathrm{~m} \mathrm{~N} \text { of } \\
\text { Mariscal mine }\end{array}$ & 0.04 & 0.04 & 0.10 & 0.49 \\
\hline MSW13 & $\begin{array}{l}600 \mathrm{~m} \mathrm{~N} \text { of } \\
\text { Mariscal mine }\end{array}$ & 0.57 & 0.63 & 0.11 & 1.0 \\
\hline MSW14 & $\begin{array}{l}1 \mathrm{~km} \mathrm{~W} \text { of } \\
\text { Mariscal mine }\end{array}$ & 0.18 & 0.29 & 0.16 & 0.24 \\
\hline MSW15 & $\begin{array}{l}3 \mathrm{~km} \mathrm{~W} \text { of } \\
\text { Mariscal mine }\end{array}$ & 0.04 & 0.01 & 0.03 & 0.32 \\
\hline \multicolumn{6}{|l|}{ Baselines } \\
\hline BSE1 & $\begin{array}{l}18 \mathrm{~km} \mathrm{E} \mathrm{of} \\
\text { Mariscal mine }\end{array}$ & 0.03 & 0.03 & 0.10 & 0.17 \\
\hline BSE2 & $\begin{array}{l}19 \mathrm{~km} \mathrm{E} \text { of } \\
\text { Mariscal mine }\end{array}$ & 0.03 & 0.02 & 0.05 & 0.35 \\
\hline BSE3 & $\begin{array}{l}20 \mathrm{~km} \mathrm{E} \text { of } \\
\text { Mariscal mine }\end{array}$ & 0.03 & 0.04 & 0.17 & 0.34 \\
\hline BSE4 & $\begin{array}{l}21 \mathrm{~km} \mathrm{NE} \text { of } \\
\text { Mariscal mine }\end{array}$ & 0.03 & 0.03 & 0.10 & 0.45 \\
\hline BSE5 & $\begin{array}{l}24 \mathrm{~km} \mathrm{NE} \text { of } \\
\text { Mariscal mine }\end{array}$ & 0.05 & 0.03 & 0.06 & 0.50 \\
\hline
\end{tabular}

Sample numbers correspond to those shown in Fig. 1

samples including an unfiltered leachate sample, and leachate water filtered at $0.70,0.45$, and $0.20 \mu \mathrm{m}$, rather than only a $0.70-\mu \mathrm{m}$ filtered sample as typically used in the 1312 Method. These four separate leachate samples were collected to evaluate if $\mathrm{Hg}$ is predominantly in a particulate form after leaching.
Water

Samples of unfiltered water were collected from surface streams, the Rio Grande, several wells and springs, and drinking water sources in and around BBNP (Fig. 1). Water samples for $\mathrm{Hg}$ and methyl-Hg analyses were collected in Teflon bottles pre-cleaned by boiling in concentrated $\mathrm{HNO}_{3}$ for $48 \mathrm{~h}$. The water samples were acidified on site with Baker Instraanalyzed ${ }^{\circledR} \mathrm{HCl}$ using a final acid concentration of $0.5 \% \mathrm{v} / \mathrm{v}$. Water samples were also collected for dissolved organic carbon (DOC) determinations in amber glass vessels. These amber bottles were precleaned by baking in a muffle furnace at $450 \mathrm{C}$ for $4 \mathrm{~h}$. The DOC water samples were filtered through $\mathrm{C}$-free $0.7-\mu \mathrm{m}$ borosilicate glass filters into the glass vessels and immediately acidified with ultra-pure $\mathrm{HCl}$ to a final acid concentration of $0.5 \% \mathrm{v} / \mathrm{v}$.

\section{Soil gas and air}

Collection of $\mathrm{Hg}$ from air and soil gas was carried out using methods similar to those previously described (Gabriel et al. 2005; Walvoord et al. 2008). Collection of $\mathrm{Hg}$ from air was made using borosilicate glass columns packed with Au-coated glass beads attached to a battery-operated pump in which air was drawn through the Au trap at a rate of $2 \mathrm{~L} / \mathrm{min}$ for $20 \mathrm{~min}$. The Au trap was attached to plastic rod at a height of $2 \mathrm{~m}$ above the ground surface. The collection line also contained a soda lime/quartz wool trap to eliminate humidity and dirt particulates from entering the $\mathrm{Au}$ trap. All Au traps used in this study were pre-cleaned in a controlled laboratory setting by heating to $350{ }^{\circ} \mathrm{C}$ under a constant stream of $\mathrm{Hg}$-free $\mathrm{Ar}$, and then, each trap was sealed using Teflon stoppers and then doublebagged in zipped plastic bags.

Collection of $\mathrm{Hg}$ from soil gas also was made using $\mathrm{Au}$ traps with soda lime traps that were attached to a flux chamber placed directly on a soil or mine waste surface (Fig. 2), and the soil gas was drawn through the trap at $2 \mathrm{~L} / \mathrm{min}$ for set times, generally $20 \mathrm{~min}$ at baseline sites and $5 \mathrm{~min}$ at mine sites. After each sample collection, the Au traps were re-plugged with a Teflon stopper, wrapped with Teflon tape, doublebagged in the zipped plastic bags, and sent to the U.S. Geological Survey (USGS) Mercury Research Laboratory (Middleton, Wisconsin) via express package delivery for $\mathrm{Hg}$ analysis. Two $\mathrm{Au}$ traps were left 


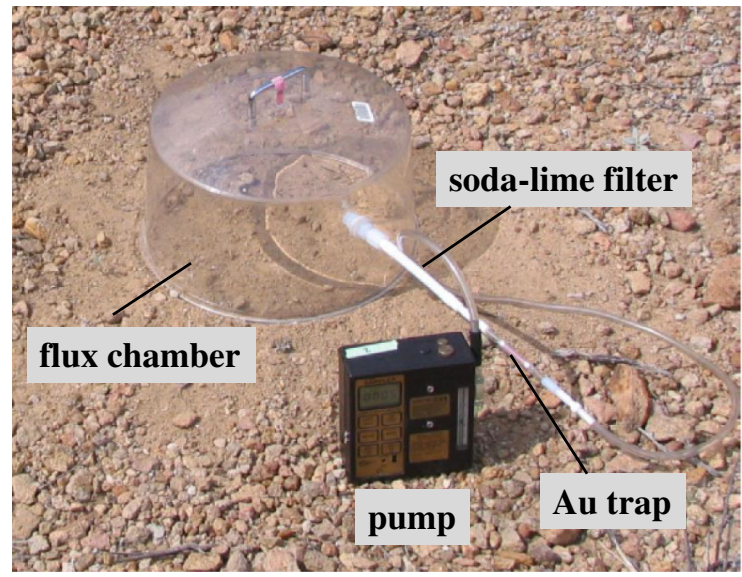

Fig. 2 Photograph of soil gas collection. Soil gas is pumped from the flux chamber, through a plastic line with a soda lime/ quartz wool filter, and $\mathrm{Hg}$ vapor is collected on a Au trap

unused per every 20 unknown traps, which were used as trip blanks to establish blank baselines.

\section{Chemical analysis}

\section{Soil and mine waste calcine}

Soil and mine waste calcine samples were analyzed for the concentration of $\mathrm{Hg}$ using cold vapor atomic fluorescence spectrometry (CVAFS) following an aqua regia digestion as outlined in USEPA Method 1631 (USEPA 2001, 2002). Concentrations of $\mathrm{Hg}$ and methyl-Hg were determined by Battelle Marine Science Laboratory, Sequim, Washington, USA. Quality control/quality assurance for $\mathrm{Hg}$ and methyl-Hg analyses was established using standard reference materials (SRM's), matrix and/or blank spikes, blind sample replicates, and method blanks. The SRM, IAEA-405 (estuarine sediment, certified value $=0.81 \mu \mathrm{g} / \mathrm{g}$ ), was analyzed with the samples and recoveries of $\mathrm{Hg}$ varied from 99 to $104 \%$ of the certified value. Blank spike samples were analyzed with the samples and recoveries for $\mathrm{Hg}$ ranged from 87 to $99 \%$. Matrix spikes of samples were also used and $\mathrm{Hg}$ recoveries ranged from 93 to $122 \%$. Analysis of blind sample replicates indicated a relative percent difference (RPD) of 5 to $7 \%$ for Hg. Method blanks were below the lower limit of determination of $5 \mathrm{ng} / \mathrm{g}$ for $\mathrm{Hg}$ analysis of these solid samples.

Concentrations of methyl-Hg were determined in the solid samples using CVAFS following USEPA
Method 1630 (USEPA 1998). To avoid possible methyl-Hg artifact effects during analysis, the samples were extracted into methylene chloride during digestion following a previously described method (Bloom et al. 1997). Recoveries of methyl-Hg varied from 78 to $86 \%$ of the certified value for IAEA-405 (certified value $=5.49 \mathrm{ng} / \mathrm{g}$ ). Recoveries of methyl $-\mathrm{Hg}$ matrix spikes in soil ranged from 78 to $105 \%$. The RPD of methyl-Hg in blind sample replicates varied from 7 to $21 \%$. Method blanks were below the lower limit of determination of $0.01 \mathrm{ng} / \mathrm{g}$ for methyl-Hg analysis of these solid samples.

Soil samples were also analyzed for total organic carbon (TOC) by subtracting carbonate $\mathrm{C}$ from total $\mathrm{C}$ concentrations. Total $\mathrm{C}$ was determined using an automated $\mathrm{C}$ analyzer with an infrared detector that measures $\mathrm{CO}_{2}$ gas liberated following sample combustion at $1,370{ }^{\circ} \mathrm{C}$. Carbonate $\mathrm{C}$ was determined by liberating $\mathrm{CO}_{2}$ following treatment with $2 \mathrm{~N} \mathrm{HClO}_{4}$, where $\mathrm{CO}_{2}$ was collected in a solution of monoethanolamine, which was then coulometrically titrated using platinum and silver/potassium-iodide electrodes. The RPD in stream sediment sample replicates was $\leq 15 \%$ for TOC, and the lower limit of determination was $0.05 \%$.

\section{Water}

Concentrations of $\mathrm{Hg}$ were determined in stream, well, and spring water samples using CVAFS following EPA Method 1631 (USEPA 2002) by Battelle Marine Sciences Laboratory. Methyl-Hg was determined in the water samples following EPA Method 1630 using CVAFS (USEPA 1998). Quality control/quality assurance for $\mathrm{Hg}$ and methyl- $\mathrm{Hg}$ analyses was evaluated using matrix spikes, SRMs, sample replicates, and method blanks. Recoveries for $\mathrm{Hg}$ using matrix spikes in water varied from 103 to $105 \%$ and for methyl-Hg were $92-100 \%$. The SRM, NIST 1641d (water solution, certified $\mathrm{Hg}$ value $=1.56 \mu \mathrm{g} / \mathrm{g}$ ), was analyzed in this study, and $\mathrm{Hg}$ recovery was $94-96 \%$ of the certified value. Samples of the SRM DORM-2 (dogfish muscle, certified value $=4.47 \mu \mathrm{g} / \mathrm{g}$ ) were digested and analyzed with the water samples to assess the accuracy of the methyl-Hg method. Recoveries of methyl-Hg for DORM-2 varied from 80 to $85 \%$ of the certified value. The RPD in water sample replicates varied from 16 to $20 \%$ for $\mathrm{Hg}$ and 4-9 \% for methyl- 
Table 2 Geochemical data for water samples

\begin{tabular}{|c|c|c|c|c|c|c|c|c|}
\hline Sample & $\begin{array}{l}\mathrm{Hg} \\
\mathrm{ng} / \mathrm{L}\end{array}$ & $\begin{array}{l}\text { Methyl-Hg } \\
\text { ng/L }\end{array}$ & $\begin{array}{l}\text { Methyl- } \mathrm{Hg} / \mathrm{Hg} \\
\%\end{array}$ & $\begin{array}{l}\mathrm{DOC} \\
\mathrm{mg} / \mathrm{L}\end{array}$ & $\mathrm{pH}$ & $\begin{array}{l}\mathrm{DO} \\
\mathrm{mg} / \mathrm{L}\end{array}$ & $\begin{array}{l}\text { Conductivity } \\
\mu \mathrm{s} / \mathrm{cm}\end{array}$ & $\begin{array}{l}\mathrm{T} \\
{ }^{\circ} \mathrm{C}\end{array}$ \\
\hline \multicolumn{9}{|c|}{ Mine runoff } \\
\hline LGD1 & 11 & 0.24 & 2.2 & 5.3 & 7.4 & 5.5 & 3,200 & 20 \\
\hline RRN1 & 14 & 0.15 & 1.0 & 5.0 & 7.9 & 4.6 & 2,030 & 27 \\
\hline TCK2 & 7.3 & 0.79 & 11 & 6.0 & 8.7 & 7.3 & 250 & 17 \\
\hline TCK3 & 7.9 & 1.2 & 15 & 6.2 & 8.3 & 6.0 & 280 & 21 \\
\hline \multicolumn{9}{|c|}{ Baseline streams } \\
\hline TOR1 & 9.3 & 0.14 & 1.5 & 3.7 & 8.1 & 3.5 & 850 & 33 \\
\hline TOR2 & 8.3 & 0.12 & 1.4 & 3.5 & 7.9 & 5.7 & 900 & 26 \\
\hline TOR3 & 9.7 & 0.11 & 1.1 & 4.5 & 8.3 & 5.7 & 980 & 21 \\
\hline Ttrbl & 4.2 & 0.07 & 1.6 & 2.9 & 7.7 & 4.9 & 1,460 & 21 \\
\hline CatFl & 1.1 & 0.03 & 3.0 & n.d. & 7.1 & 5.5 & 400 & 19 \\
\hline TCK1 & 2.1 & 0.61 & 11 & 6.2 & 8.6 & 6.5 & 270 & 16 \\
\hline \multicolumn{9}{|c|}{ Springs and wells } \\
\hline Hotl & 1.5 & 0.03 & 2.1 & 1.1 & 7.3 & n.d. & 1,300 & 41 \\
\hline GlnS1 & 1.5 & 0.02 & 1.4 & 1.6 & 7.6 & 6.0 & 710 & 23 \\
\hline Mosql & 1.2 & $<0.02$ & $<0.83$ & n.d. & 7.3 & 3.1 & 1,270 & 33 \\
\hline CrotS1 & 3.1 & 0.07 & 2.1 & 1.8 & 8.8 & 6.1 & 3,520 & 20 \\
\hline OakSl & 1.1 & 0.02 & 1.9 & 1.1 & 7.4 & 5.3 & 380 & 16 \\
\hline Snaill & 0.54 & $<0.02$ & $<1.9$ & 1.0 & 7.1 & 4.1 & 220 & 20 \\
\hline MEarl & 0.05 & $<0.02$ & $<20$ & n.d. & 7.4 & 6.0 & 530 & 25 \\
\hline ButlSl & 0.33 & $<0.02$ & $<3.0$ & n.d. & 7.4 & 4.8 & 420 & 23 \\
\hline \multicolumn{9}{|c|}{ Drinking water } \\
\hline BASN1 & 6.9 & $<0.02$ & $<0.14$ & 1.0 & 7.6 & 5.0 & 390 & 19 \\
\hline CAST 1 & 0.74 & $<0.02$ & $<1.4$ & 1.2 & 7.9 & 5.1 & 510 & 20 \\
\hline RGV1 & 1.0 & $<0.02$ & $<1.0$ & n.d. & 7.2 & 1.9 & 1,250 & 35 \\
\hline RGVC & 1.1 & $<0.02$ & $<0.91$ & n.d. & 7.3 & 5.3 & 1,120 & 22 \\
\hline BARK1 & 0.63 & $<0.02$ & $<1.6$ & 1.1 & 7.1 & 3.0 & 1,100 & 26 \\
\hline PANJ1 & 9.1 & 0.10 & 1.1 & n.d. & 7.5 & 4.2 & 390 & 25 \\
\hline \multicolumn{9}{|c|}{ Rio Grande } \\
\hline RIO1 & 13 & 0.35 & 2.7 & 4.0 & 7.9 & 5.5 & 1,590 & 22 \\
\hline RIO2 & 6.5 & 0.90 & 14 & 4.8 & 8.0 & 5.5 & 1,140 & 20 \\
\hline RIO3 & 3.0 & 0.28 & 9.3 & 3.1 & 7.8 & 4.3 & 1,390 & 21 \\
\hline RIO4 & 2.7 & 0.34 & 13 & 3.7 & 7.8 & 4.7 & 910 & 22 \\
\hline RIO5 & 7.3 & 1.9 & 26 & 6.9 & 7.8 & 4.5 & 760 & 21 \\
\hline RIO5F & 6.5 & 0.22 & 3.3 & 3.5 & 8.2 & 8.1 & 1,410 & 22 \\
\hline RIO6 & 3.2 & 0.51 & 16 & 3.3 & 7.8 & 5.2 & 770 & 20 \\
\hline RIO7 & 2.9 & 0.31 & 11 & 3.2 & 7.6 & 7.4 & 790 & 21 \\
\hline RIO8 & 4.0 & 0.60 & 15 & 3.2 & 7.6 & 6.8 & 980 & 22 \\
\hline RIO9 & 3.8 & 0.58 & 15 & 3.4 & 7.8 & 7.9 & 1,600 & 22 \\
\hline
\end{tabular}

Sample numbers correspond to those shown in Fig. 1

$\mathrm{Hg}$. Method blanks were less than the lower limit of determination of $0.2 \mathrm{ng} / \mathrm{L}$ for $\mathrm{Hg}$ and $0.02 \mathrm{ng} / \mathrm{L}$ for methyl-Hg in water.
DOC was determined in the water samples collected in this study using a Shimadzu TOC- $\mathrm{V}_{\mathrm{CSH}}$ instrument at the USGS, Denver, Colorado. In the 
water samples, organic carbon was oxidized to $\mathrm{CO}_{2}$ by high temperature catalytic oxidation and $\mathrm{CO}_{2}$ was measured by a non-dispersive infrared detector. The precision of the DOC method was $\pm 10 \%$. Field and method blanks contained DOC below the lower limit of determination of $0.3 \mathrm{mg} / \mathrm{L}$. Several on-site field measurements were also taken in water using a Hydrolab Quanta ${ }^{\circledR}$ instrument, but of these only temperature, $\mathrm{pH}$, dissolved oxygen, and electrical conductivity are reported here (Table 2).

\section{Leachates}

Concentrations of $\mathrm{Hg}$ were determined in water leachate samples using CVAFS at the USGS, Denver, following a previously published method (Kennedy and Crock 1987). Quality control/quality assurance for $\mathrm{Hg}$ analysis of these leachates was addressed through the use of several internal water laboratory standards, sample replicates, and method blanks. The RPD of $\mathrm{Hg}$ in sample replicates varied from 3 to $17 \%$. Recovery of $\mathrm{Hg}$ from internal laboratory standards varied from 87 to $97 \%$. Method blanks were less than the lower limit of determination of $5 \mathrm{ng} / \mathrm{L}$ for $\mathrm{Hg}$.

\section{Air and soil gas $\mathrm{Hg}$}

In the laboratory, $\mathrm{Hg}$ amalgamated to the Au beads on the sample traps was quantified by thermal desorption of the $\mathrm{Hg}$ at $450{ }^{\circ} \mathrm{C}$ onto an ultra-high purity Ar carrier gas, which was then detected by CVAFS using a Tekran model 2,500 Hg detector at the USGS Mercury Research Laboratory. Quality control/quality assurance was addressed using trip blank Au traps and blind sample replicates. Trip blanks indicated a lower limit of determination of $0.03 \mathrm{ng}$. The RPD $\mathrm{Hg}$ for blind sample replicates was 9-19\%.

\section{Results and discussion}

\section{Soil}

Samples of A-horizon soil collected within $300 \mathrm{~m}$ of the Mariscal mine site contained elevated concentrations of $\mathrm{Hg}$ that ranged from 3.8 to $11 \mu \mathrm{g} / \mathrm{g}$ (Table 1 , Fig. 3). Other soil samples collected more distally (>300 m, up to $7.5 \mathrm{~km}$ ) from the Mariscal mine contained considerably lower $\mathrm{Hg}$ concentrations that

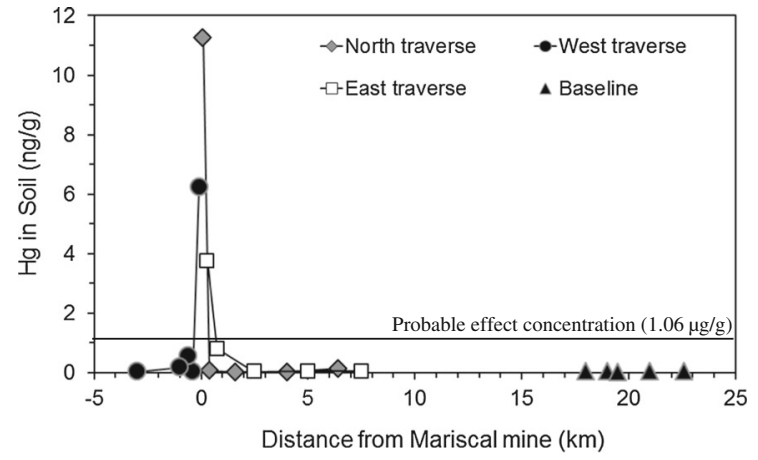

Fig. 3 Concentration of $\mathrm{Hg}$ in soil versus distance from the Mariscal mine. Negative distances are those for the west traverse. The probable effect concentration for $\mathrm{Hg}$ (MacDonald et al. 2000) is shown for reference

varied from 0.02 to $0.81 \mu \mathrm{g} / \mathrm{g}$ (Fig. 3). Soil collected from the most distal locations along each of the three transects contained $\mathrm{Hg}$ that varied from 0.04 to $0.14 \mu \mathrm{g} / \mathrm{g}$ and was similar to $\mathrm{Hg}$ found in soil collected from uncontaminated baseline sites $(0.03-0.05 \mu \mathrm{g} / \mathrm{g})$. Only 3 of the 20 collected soil samples (those closest to the mine, Fig. 3) exceeded the probable effect concentration for $\mathrm{Hg}$ of $1.06 \mu \mathrm{g} / \mathrm{g}$, above which harmful effects are likely to be observed in sediment-dwelling organisms (MacDonald et al. 2000). Similarly, concentrations of $\mathrm{Hg}$ in the three soil samples collected most proximal to the Mariscal mine exceeded the $2.3 \mu \mathrm{g} / \mathrm{g}$ USEPA residential soil screening level (SSL), whereas $\mathrm{Hg}$ in all soil samples were lower than the $31 \mu \mathrm{g} / \mathrm{g}$ USEPA industrial SSL for $\mathrm{Hg}$ (USEPA 2013). These Hg data indicate local, windblown transport of mine waste primarily in soil within about $300 \mathrm{~m}$ of the mine site, although there was no correlation of $\mathrm{Hg}$ concentration with wind direction.

Methyl-Hg shows a similar pattern where soil collected within $750 \mathrm{~m}$ of the mine contained methyl$\mathrm{Hg}$ concentrations that varied from 0.04 to $0.63 \mathrm{ng} / \mathrm{g}$, whereas soil samples collected up to $7.5 \mathrm{~km}$ from the mine contain methyl-Hg concentrations that varied from 0.01 to $0.29 \mathrm{ng} / \mathrm{g}$ (Table 1). Soil collected from uncontaminated baseline sites was found to contain the lowest methyl-Hg concentrations, which ranged from 0.02 to $0.04 \mathrm{ng} / \mathrm{g}$. The ratio of methyl $-\mathrm{Hg} / \mathrm{Hg}$ in soil was generally low $(<1 \%$, Table 1$)$, which is consistent with that found in other studies of $\mathrm{Hg}$ mines (Hines et al. 2000; Ullrich et al. 2001; Rimondi et al. 2012). All concentrations of methyl-Hg in the soil samples were lower than the USEPA methyl-Hg 


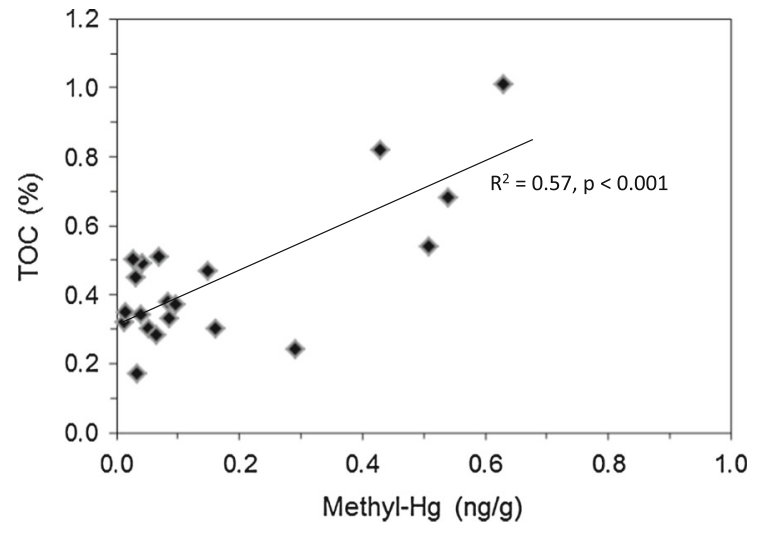

Fig. 4 Concentration of methyl-Hg versus total organic carbon (TOC) in soil

residential SSL of $0.78 \mu \mathrm{g} / \mathrm{g}$ and the industrial SSL of $10 \mu \mathrm{g} / \mathrm{g}$ (USEPA 2013). Soil samples collected in this study show a correlation between methyl-Hg and TOC ( $r^{2}=0.57, p<0.001$; Fig. 4), which is consistent with the affinity of methyl-Hg for organic matter and similar to results found in other studies of $\mathrm{Hg}$ mined areas (Rimondi et al. 2012; Tomiyasu et al. 2012). The methyl-Hg data for soil indicate generally low conversion of inorganic $\mathrm{Hg}$ (dominantly $\mathrm{HgS}$ ) to the highly toxic methyl-Hg.

\section{Water}

Water was collected from streams draining mined areas, streams distant from mines, the Rio Grande, hot and cold springs, wells, and drinking water supplies in and around BBNP (Fig. 1, Table 2). The highest $\mathrm{Hg}$ concentrations were found in mine water runoff, which varied from 7.9 to $-14 \mathrm{ng} / \mathrm{L}(n=4$; Table 2$)$. Methyl-Hg in mine runoff water ranged from 0.15 to $1.2 \mathrm{ng} / \mathrm{L}$ and was also among the highest in this study (Fig. 5). The highest $\mathrm{Hg}$ concentration (14 ng/L) was found in water collected from a tributary of Terlingua Creek that receives runoff from the Study Butte mine (Fig. 1, Table 2). Water collected from the Rio Grande was also elevated in $\mathrm{Hg}$ and methyl-Hg where $\mathrm{Hg}$ varied from 2.7 to $13 \mathrm{ng} / \mathrm{L}(n=10)$ and methyl$\mathrm{Hg}$ varied from 0.22 to $1.9 \mathrm{ng} / \mathrm{L}$ (Table 2, Fig. 5). The highest $\mathrm{Hg}$ concentration in Rio Grande water was collected from the site farthest upstream (RIO 1, $13 \mathrm{ng} / \mathrm{L}$ ), which is upstream from mines of the Terlingua district, and thus, $\mathrm{Hg}$ at this site is likely from other upstream point sources in Mexico and the
USA. Potential sources of $\mathrm{Hg}$ upstream from this site are most likely anthropogenic sources such as industrial, urban, and agricultural runoff. Lower concentrations of $\mathrm{Hg}$ were found in springs, wells, and drinking water supplies in BBNP, which varied from 0.05 to $9.1 \mathrm{ng} / \mathrm{L}$ (Table 2). Methyl-Hg in these water sources was the lowest in this study and varied from $<0.02$ to $0.10 \mathrm{ng} / \mathrm{L}$. Baseline water samples were collected at sites distant from mines on Tornillo Creek and tributaries of Terlingua Creek, and $\mathrm{Hg}$ in these samples varied from 2.1 to $9.7 \mathrm{ng} / \mathrm{L} \quad(n=6)$, a variation generally similar to that of drinking water supplies in the study area. Methyl- $\mathrm{Hg}$ in baseline streams was generally low and varied from 0.03 to $0.14 \mathrm{ng} / \mathrm{L}$. Dissolved oxygen in surface water samples indicate that water is generally oxidized in this environment (Table 2). The dominant form of $\mathrm{Hg}$ in such water is likely $\mathrm{Hg}^{2+}$ and methylation of $\mathrm{Hg}$ is generally low in oxidized environments (USEPA 1997). Similar to results for soil, the ratio of methyl$\mathrm{Hg} / \mathrm{Hg}$ was generally low $(<3 \%)$ in water samples analyzed in this study (Table 2). However, water collected from the Rio Grande was found to have methyl- $\mathrm{Hg} / \mathrm{Hg}$ as high as $26 \%$, which was likely due to generally higher DOC in these samples (Table 2).

Concentrations of $\mathrm{Hg}$ in all water samples collected in this study were considerably below established water quality guidelines for $\mathrm{Hg}$ including (1) the 2,000 $\mathrm{ng} / \mathrm{L}$ drinking water $\mathrm{Hg}$ guideline recommended by the USEPA (USEPA 2009), (2) the $6,000 \mathrm{ng} / \mathrm{L}$ international drinking water $\mathrm{Hg}$ guideline recommended by the World Health Organization (WHO 2005), and (3) the USEPA $770 \mathrm{ng} / \mathrm{L}$ guideline recommended to protect aquatic wildlife against chronic effects of $\mathrm{Hg}$ (USEPA 1995). There is no recommended guideline for methyl-Hg in drinking water. However, water collected in this study indicated a significant correlation between methyl-Hg and DOC $\left(R^{2}=0.56, p<0.001\right.$; Fig. 6) suggesting that methyl-Hg has strong binding with DOC or that methylation of $\mathrm{Hg}$ is higher in the presence of DOC as found in other studies (Berndt and Bavin 2012; Alpers et al. 2013). A similar result was observed between methyl-Hg and TOC in soil samples.

Leachates

Water leach studies were carried out on mine waste calcine samples collected from several localities 


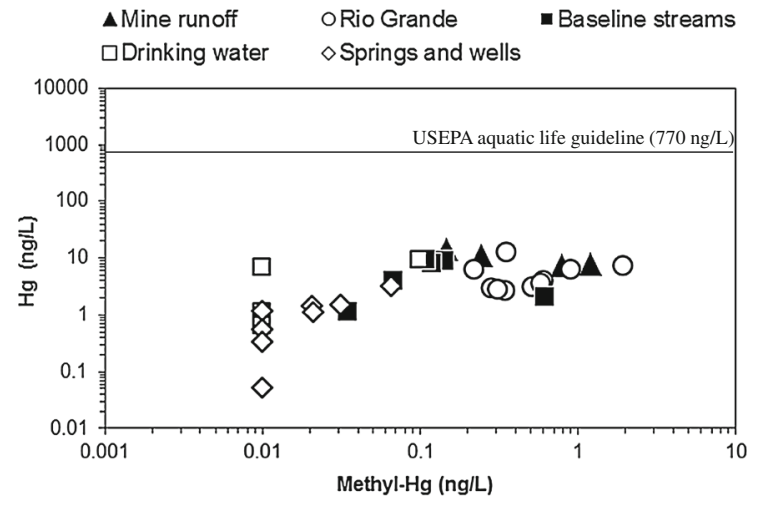

Fig. 5 Concentration of $\mathrm{Hg}$ versus methyl- $\mathrm{Hg}$ in water. The USEPA guideline recommended to protect aquatic wildlife from chronic effects of $\mathrm{Hg}$ (USEPA 1995) is shown for reference

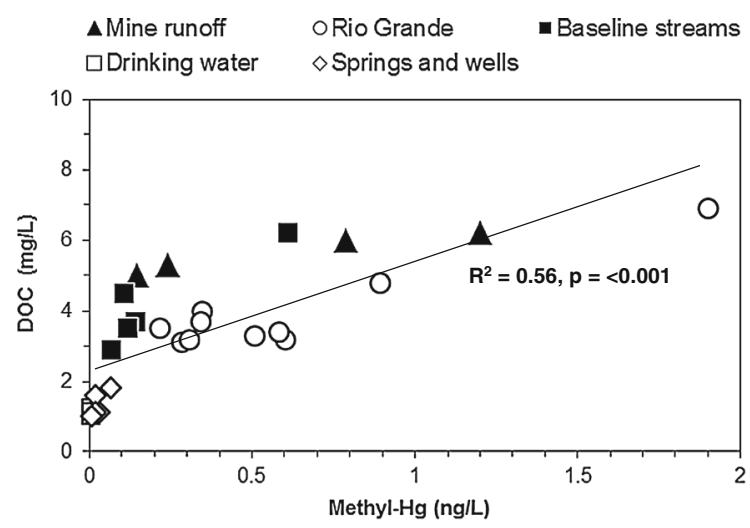

Fig. 6 Concentration of methyl-Hg versus dissolved organic carbon (DOC) in water

because the study area is in an arid desert climate with little annual precipitation. Only four mine runoff water samples were collected in this study, and therefore, the USEPA 1312 synthetic precipitation leaching procedure was used to simulate potential leaching of $\mathrm{Hg}$ from mine waste during periods of precipitation. The obtained water leachates were filtered at $0.7,0.45$, and $0.2 \mu \mathrm{m}$ to evaluate if $\mathrm{Hg}$ in the leachates was dominantly in the suspended or dissolved fraction.

Concentrations of $\mathrm{Hg}$ in the leachates varied widely from $<0.001$ to $760 \mu \mathrm{g}$ of $\mathrm{Hg}$ in leachate/g of sample leached (Table 3, Fig. 7). The total amount of $\mathrm{Hg}$ leached from the mine waste was generally low and varied from 0.02 to $4.1 \%$ (based on $\mathrm{Hg}$ concentrations in the unfiltered leachates). These data are similar to, or lower than, results from other water leach studies (Gray et al. 2010). There is no recommended guideline for $\mathrm{Hg}$ in water leachates, so the leachate $\mathrm{Hg}$ concentrations ( $\mathrm{Hg}$ in leachate/g of sample leached) were compared to the USEPA $\mathrm{Hg}$ industrial SSL (USEPA 2013). Concentrations of $\mathrm{Hg}$ in leachates were generally found to be lower than the $31 \mu \mathrm{g} / \mathrm{g}$ industrial SSL (USEPA 2013). Although all Hg concentrations in the mine waste calcine samples exceeded this industrial SSL, only the $\mathrm{Hg}$ concentration of one unfiltered leachate (Ter1rt, $760 \mu \mathrm{g} / \mathrm{g}$ ), which was collected from inside an abandoned retort near the town of Terlingua, exceeded this SSL guideline. Concentration of $\mathrm{Hg}$ in leachates generally decreases with decreasing pore size of filtration indicating that $\mathrm{Hg}$ in the leachates is dominantly suspended particulate $\mathrm{Hg}$, most likely suspended particulate cinnabar released during leaching.

Air and soil gas $\mathrm{Hg}$

Concentrations of $\mathrm{Hg}$ were measured in soil gas and air at mined and baseline sites in this study to evaluate the variability of $\mathrm{Hg}$ near ground surfaces in and around BBNP (Table 4). Concentration of $\mathrm{Hg}$ in these air and soil gas samples ranged widely from 1.2 to $82,000 \mathrm{ng} / \mathrm{m}^{3}$ (Fig. 8). The highest $\mathrm{Hg}$ concentrations were found in soil gas emitted from an area around an abandoned brick retort at the Mariscal mine, which varied from 19,000 to $82,000 \mathrm{ng} / \mathrm{m}^{3}$ (Table 4). Highly elevated $\mathrm{Hg}$ concentrations were also observed in soil gas collected from mine waste calcine piles at three mined sites, which ranged from 690 to $1,600 \mathrm{ng} / \mathrm{m}^{3}$ (Table 4). Such highly elevated $\mathrm{Hg}$ concentrations reflect the presence of $\mathrm{Hg}_{(\mathrm{L})}^{0}$ in mine waste, which has been reported in previous studies (Kim et al. 2003; Gray et al. 2010). Conversely, concentrations of $\mathrm{Hg}$ measured in ambient air $2 \mathrm{~m}$ above the ground surface at these mined sites were found to be as much as several orders of magnitude lower, ranging from 4.9 to $64 \mathrm{ng} / \mathrm{m}^{3}$. These $2 \mathrm{~m} \mathrm{Hg}$ air data suggest that although concentrations of $\mathrm{Hg}$ emitted from mine waste in mined areas were elevated, persistent wind in southwest Texas disperses $\mathrm{Hg}$ in air within a few meters of the ground surface. Other studies have observed decreasing $\mathrm{Hg}$ emissions from soil in mined areas over periods of hours to days (García-Sánchez et al. 2006; Higueras et al. 2012), but long-term $\mathrm{Hg}$ emissions from soil was not evaluated in this study. Concentrations of $\mathrm{Hg}$ reported in this study for air and 
Table 3 Concentrations of $\mathrm{Hg}$ for leachates of mine waste samples

\begin{tabular}{|c|c|c|c|c|c|c|}
\hline Sample & Description & $\begin{array}{l}\text { Mine } \\
\text { waste } \\
\mathrm{Hg}(\mu \mathrm{g} / \\
\mathrm{g})\end{array}$ & $\begin{array}{l}\text { Unfiltered } \\
\mu \mathrm{g} \mathrm{Hg} \text { leached/g } \\
\text { sample }\end{array}$ & $\begin{array}{l}0.7 \mathrm{~nm} \\
\mu \mathrm{g} \mathrm{Hg} \mathrm{leached} / \mathrm{g} \\
\text { sample }\end{array}$ & $\begin{array}{l}0.45 \mu \mathrm{m} \\
\mu \mathrm{g} \mathrm{Hg} \mathrm{leached} / \mathrm{g} \\
\text { sample }\end{array}$ & $\begin{array}{l}0.2 \mu \mathrm{m} \\
\mu \mathrm{g} \mathrm{Hg} \text { leached/g } \\
\text { sample }\end{array}$ \\
\hline Mar1rt & Mariposa mine, retort & 170 & 7.0 & 1.4 & 1.3 & 0.23 \\
\hline Mar2 & Mariposa mine, calcine & 190 & 1.1 & 0.098 & 0.10 & 0.11 \\
\hline Mar3 & Mariposa mine, calcine & 35 & 0.15 & 0.012 & 0.006 & 0.005 \\
\hline Mar4 & Mariposa mine, calcine & 25 & 0.81 & 0.012 & 0.012 & 0.012 \\
\hline Mar5 & Mariposa mine, calcine & 13 & 0.13 & 0.005 & 0.011 & 0.006 \\
\hline Ter1rt & Terlingua mine, retort & 19,000 & 760 & 16 & 16 & 20 \\
\hline Ter2 & Terlingua mine, calcine & 14 & 0.040 & 0.015 & 0.021 & 0.020 \\
\hline Ter3 & Terlingua mine, calcine & 16 & 0.12 & 0.005 & 0.005 & 0.006 \\
\hline Ter4 & Terlingua mine, calcine & 170 & 0.030 & 0.002 & 0.002 & $<0.001$ \\
\hline Ter5 & Terlingua mine, calcine & 4.1 & 0.040 & 0.003 & 0.002 & $<0.001$ \\
\hline MSM1 & Mariscal mine, calcine & 6.9 & 0.046 & $<0.001$ & $<0.001$ & $<0.001$ \\
\hline MSM2 & Mariscal mine, calcine & 31 & 0.040 & $<0.001$ & $<0.001$ & 0.002 \\
\hline MSM3 & Mariscal mine, calcine & 44 & 0.31 & $<0.001$ & $<0.001$ & $<0.001$ \\
\hline MSM4 & Mariscal mine, calcine & 110 & 0.66 & $<0.001$ & $<0.001$ & $<0.001$ \\
\hline MSM5 & Mariscal mine, calcine & 150 & 0.62 & $<0.001$ & $<0.001$ & $<0.001$ \\
\hline SB1rt & Study Butte mine, retort & 5,900 & 24 & 2.4 & 2.0 & 1.5 \\
\hline SB2 & $\begin{array}{l}\text { Study Butte mine, } \\
\text { calcine }\end{array}$ & 12 & 0.13 & 0.006 & 0.006 & 0.007 \\
\hline SB3 & $\begin{array}{l}\text { Study Butte mine, } \\
\text { calcine }\end{array}$ & 480 & 0.61 & 0.002 & $<0.001$ & $<0.001$ \\
\hline SB4 & $\begin{array}{l}\text { Study Butte mine, } \\
\text { congener soot }\end{array}$ & 3,000 & 6.6 & 0.048 & 0.009 & 0.007 \\
\hline SB5 & $\begin{array}{l}\text { Study Butte mine, } \\
\text { calcine }\end{array}$ & 35 & 1.2 & 0.002 & 0.002 & 0.002 \\
\hline
\end{tabular}

Sample numbers correspond to those shown in Fig. 1

soil gas in mined areas are similar to, or higher than, $\mathrm{Hg}$ measured in other areas mined for $\mathrm{Hg}$, where concentrations of $\mathrm{Hg}$ have been reported to vary from 100 to $6,000 \mathrm{ng} / \mathrm{m}^{3}$ (Ferrara et al. 1991, 1998b).

Concentrations of $\mathrm{Hg}$ in air and soil gas from the baseline sites were among the lowest in this study. Soil gas $\mathrm{Hg}$ at the baseline sites varied from 2.6 to $77 \mathrm{ng} /$ $\mathrm{m}^{3}$, whereas air collected at $2 \mathrm{~m}$ above the ground surface ranged from 1.2 to $6.0 \mathrm{ng} / \mathrm{m}^{3}$. However, one of the baseline sites (IHM-b, Fig. 1) was within $2 \mathrm{~km}$ and downwind from the Study Butte mine, this site had the highest $\mathrm{Hg}$ concentrations of the baseline sites and was potentially affected by windblown particulates from this mine (Fig. 1, Table 4). Concentrations of $\mathrm{Hg}$ measured in air at the $2 \mathrm{~m}$ height at the baselines sites were generally similar to that found for atmospheric $\mathrm{Hg}$ worldwide, which has been reported to range from
1 to $9 \mathrm{ng} / \mathrm{m}^{3}$ (Fitzgerald 1986; Porcella 1994; Lamborg et al. 2002). In this study, concentrations of $\mathrm{Hg}$ in all of the air collected $2 \mathrm{~m}$ above the ground surface were below two $\mathrm{Hg}$ in air guidelines recommended by the Agency for Toxic Substances and Disease Registry (ATSDR): (1) the $1,000 \mathrm{ng} / \mathrm{m}^{3}$ residential indoor air action level (remediation is needed if this level is exceeded) and (2) the $200 \mathrm{ng} / \mathrm{m}^{3}$ minimal risk level for chronic exposures of $\mathrm{Hg}$ (more than 365 days) for indoor workspace (ATSDR 2012). These ATSDR guidelines are for closed air spaces and thus are not directly comparable to the air and soil gas $\mathrm{Hg}$ data shown here. In addition, the World Health Organization recommends a "no-observed-adverse-effect" guideline of $1,000 \mathrm{ng} / \mathrm{m}^{3}$ for $\mathrm{Hg}$ vapor in air (WHO 2000). There are numerous homes and business buildings in and around the town of Terlingua, but 


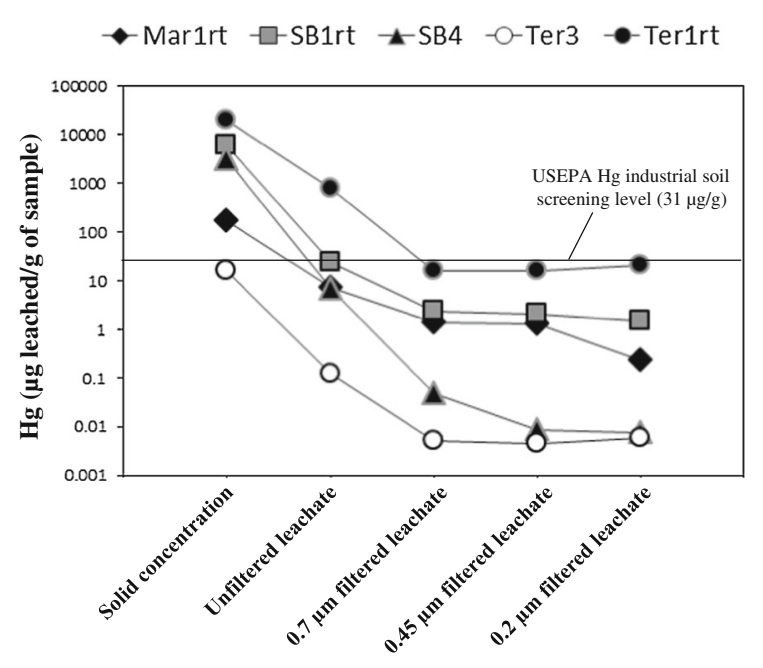

Fig. 7 Concentration of $\mathrm{Hg}$ in various leachates obtained from leaching of mine waste calcine samples using the USEPA method 1312, synthetic precipitation leaching procedure (USEPA 1994). Sample numbers correspond to those in Table 3. The USEPA industrial soil screening level for $\mathrm{Hg}$ is shown for reference (USEPA 2013)

concentrations of $\mathrm{Hg}$ were not measured in closed building air spaces in this study, and thus, any adverse effects to residents in this area are unknown. There are no homes or permanent structures at the Mariscal mine site in BBNP.

Using another approach, $\mathrm{Hg}$ concentrations were converted to $\mathrm{Hg}$ flux using:

$F=Q\left(\left(C_{0}-C_{1}\right) / A\right)$

where $F$ is the flux of $\mathrm{Hg}\left(\mathrm{ng} / \mathrm{m}^{2} / \mathrm{h}\right), Q$ is the flow rate through the chamber $\left(\mathrm{m}^{3} / \mathrm{h}\right), C_{\mathrm{o}}$ is the soil gas $\mathrm{Hg}$ concentration $\left(\mathrm{ng} / \mathrm{m}^{3}\right), \mathrm{C}_{\mathrm{i}}$ is the ambient air $\mathrm{Hg}$ concentration $\left(\mathrm{ng} / \mathrm{m}^{3}\right)$, and $A$ is the area of the chamber $\left(\mathrm{m}^{2}\right)$. Similar to the results for $\mathrm{Hg}$ concentrations, calculated $\mathrm{Hg}$ flux at the studied mined sites was found to be highly elevated ranging from 1,050 to $56,700 \mathrm{ng} / \mathrm{m}^{2} / \mathrm{h}$ (Table 4). Such highly elevated $\mathrm{Hg}$ flux in the Big Bend region is similar to, or higher than, that observed in other mined areas, which has been reported to be as high as $27,600 \mathrm{ng} / \mathrm{m}^{2} / \mathrm{h}$ (Engle et al. 2001; Wang et al. 2005; Eckley et al. 2010; Higueras et al. 2014). Although $\mathrm{Hg}$ emissions are high in such mined areas, some studies have indicated that $\mathrm{Hg}$ emissions from areas mined for $\mathrm{Hg}$ are a smaller source of $\mathrm{Hg}$ to the global budget of $\mathrm{Hg}$ compared to much larger sources such as fossil fuel burning, evaporation from oceans, and various land sources
Table 4 Concentration and flux of $\mathrm{Hg}$ in soil gas and air

\begin{tabular}{|c|c|c|c|c|}
\hline Mines & $n$ & $\begin{array}{l}\mathrm{Hg} \\
\mathrm{ng} / \mathrm{m}^{3}\end{array}$ & $\begin{array}{l}\mathrm{Hg} \text { (mean) } \\
\mathrm{ng} / \mathrm{m}^{3}\end{array}$ & $\begin{array}{l}\text { Flux } \\
\mathrm{ng} / \mathrm{m}^{3} / \mathrm{h}\end{array}$ \\
\hline \multicolumn{5}{|l|}{ Study Butte } \\
\hline Soil gas-calcine & 10 & $1,000-1,600$ & 1,270 & 1,630 \\
\hline $\begin{array}{l}\text { Air @ } 2 \text { m } \\
\text { Mariscal }\end{array}$ & 10 & $16-57$ & 36 & \\
\hline Soil gas-retort & 10 & $19,000-82,000$ & 43,000 & 56,700 \\
\hline Soil gas-calcine & 12 & $690-1,500$ & 990 & 1,260 \\
\hline $\begin{array}{l}\text { Air@2 m } \\
\text { Terlingua }\end{array}$ & 16 & $16-64$ & 35 & \\
\hline Soil gas-calcine & 8 & $720-910$ & 803 & 1,050 \\
\hline $\begin{array}{l}\text { Air@2 m } \\
\text { Baselines }\end{array}$ & 8 & $4.9-7.6$ & 6.1 & \\
\hline$D a g F-b$ & & & & \\
\hline Soil gas & 9 & $3.0-17$ & 8.9 & 7.9 \\
\hline $\begin{array}{l}\text { Air@ } @ 2 \mathrm{~m} \\
G V H-b\end{array}$ & 6 & $1.2-6.0$ & 2.9 & \\
\hline Soil gas & 9 & $3.1-28$ & 14 & 15 \\
\hline $\begin{array}{l}\text { Air@2m } \\
M A V-b\end{array}$ & 6 & $1.2-5.0$ & 2.5 & \\
\hline Soil gas & 9 & $3.0-12$ & 6.6 & 5.9 \\
\hline $\begin{array}{l}\text { Air@ } 2 \mathrm{~m} \\
B O Q-b\end{array}$ & 6 & $1.4-3.0$ & 2.1 & \\
\hline Soil gas & 3 & $2.6-4.2$ & 3.6 & 2.1 \\
\hline $\begin{array}{l}\text { Air@ } 2 \text { m } \\
\text { BoneS-b }\end{array}$ & 3 & $1.9-2.1$ & 2.0 & \\
\hline Soil gas & 3 & $25-32$ & 28 & 33 \\
\hline $\begin{array}{l}\text { Air@ } 2 \text { m } \\
I H M-b\end{array}$ & 3 & $2.1-5.0$ & 3.0 & \\
\hline Soil gas & 3 & $71-77$ & 73 & 90 \\
\hline Air @ 2 m & 4 & $3.1-6.0$ & 4.5 & \\
\hline
\end{tabular}

Mines studied and baseline sample numbers correspond to those shown in Fig. 1

(Mason et al. 1994; Ferrara et al. 1998a; Fitzgerald et al. 1998; Lamborg et al. 2002; Kocman et al. 2013). Studies of $\mathrm{Hg}$ emissions at Almadén, Spain, the world's largest $\mathrm{Hg}$ district from which $\mathrm{Hg}$ production was several orders of magnitude greater than that in the Terlingua district, indicated that $\mathrm{Hg}$ emissions from Almadén represented only about $0.1 \%$ of the global anthropogenic $\mathrm{Hg}$ emissions (Ferrara et al. 1998a; Higueras et al. 2013). Furthermore, other studies have indicated that $\mathrm{Hg}$ emissions from all mined areas worldwide contribute about $1-2 \%$ of the total atmospheric budget of $\mathrm{Hg}$ (Hudson et al. 1995; Kocman et al. 2013). 


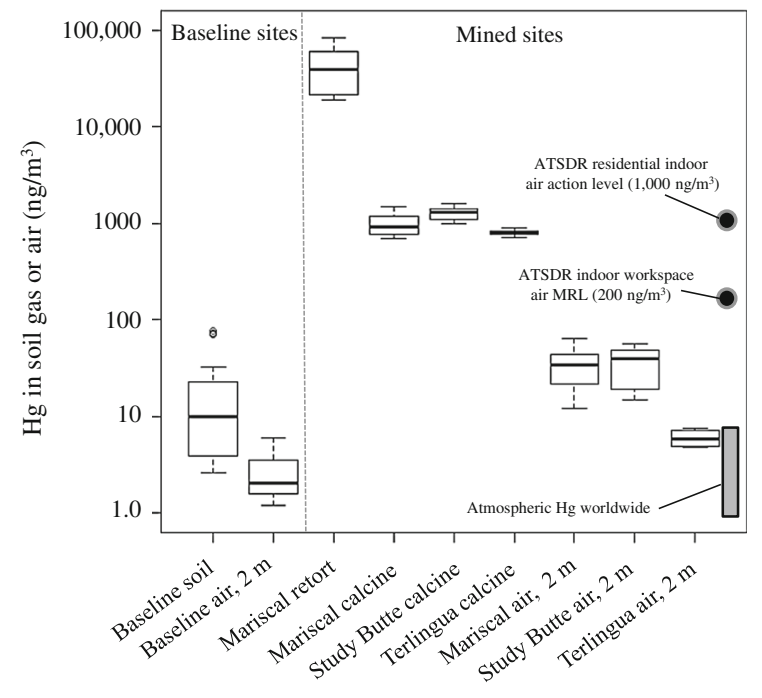

Fig. 8 Box and whisker plot of $\mathrm{Hg}$ in soil gas and air samples. The box represents the interquartile range (IQR), where the upper and lower limit of the box represents the 0.75 and 0.25 quartile of the data, respectively. The solid line in the box is the median data point. The top and bottom whiskers are $1.5 \mathrm{X}$ the IQR. The open circles (o) outside of the whiskers are outlier data exceeding 1.5 X the IQR. Points of reference for indoor air space are from the ATSDR, Agency for Toxic Substances and Disease Registry (ATSDR 2012). The range of concentration for atmospheric $\mathrm{Hg}$ worldwide (Fitzgerald 1986; Porcella 1994; Lamborg et al. 2002) is also shown for reference

\section{Conclusions}

Although concentrations of $\mathrm{Hg}$ in soil and water collected proximal to mines in this study were elevated, $\mathrm{Hg}$ in similar samples collected more distally from mines were generally lower, indicating considerable dispersion of $\mathrm{Hg}$ in soil and water in the region. Concentrations of $\mathrm{Hg}$ in all soil samples were lower than the USEPA industrial SSL for Hg. Similarly, concentrations of $\mathrm{Hg}$ in all water samples collected in this study were found to be below recommended drinking water and aquatic life $\mathrm{Hg}$ guidelines in the USA. Methyl-Hg in soil showed a significant correlation with TOC $\left(r^{2}=0.57, p<0.001\right)$, and similarly, methyl-Hg in water correlated significantly with DOC $\left(R^{2}=0.56\right.$, $p<0.001$ ), results which are consistent with the affinity of methyl-Hg for organic matter. Concentrations of $\mathrm{Hg}$ in leachates of mine waste were generally found to be lower than the USEPA Hg industrial SSL. Soil gas and air collected from mined areas contained $\mathrm{Hg}$ that was considerably higher than that found at uncontaminated baseline sites in the region. Concentrations of $\mathrm{Hg}$ in air collected $2 \mathrm{~m}$ above the ground surface at mined areas were found to be several orders of magnitude lower than $\mathrm{Hg}$ in soil gas collected at ground level from mine wastes. The soil gas and air $\mathrm{Hg}$ data indicate that persistent wind in southwest Texas disperses $\mathrm{Hg}$ in air within a few meters of the ground surface.

Human exposure to $\mathrm{Hg}$ in this region is mostly likely from long-term exposure to $\mathrm{Hg}$ vapor in closed spaces such as buildings and residences and/or hand-to-mouth ingestion of soil or airborne mine wastes particles containing elevated $\mathrm{Hg}$. There are no homes or permanent structures on the Mariscal $\mathrm{Hg}$ mine in BBNP, but Mariscal is a site often visited by tourists and human exposure to $\mathrm{Hg}$ through inhalation of $\mathrm{Hg}$ rich dust particulates is short term and should be limited as much as possible. There are numerous homes in the town of Terlingua, which are located around abandoned $\mathrm{Hg}$ mines. Concentrations of $\mathrm{Hg}$ were not measured in closed building air spaces in this study, and any adverse effects to residents in this area are unknown. However, data shown herein for $\mathrm{Hg}$ in soil gas and air indicate rapid dispersion of $\mathrm{Hg}$ in air due to dispersion by persistent wind. Proper ventilation of closed air spaces would likely reduce human exposure to $\mathrm{Hg}$ vapor. Human exposure to methyl$\mathrm{Hg}$, a highly toxic $\mathrm{Hg}$ compound, is also of concern around any $\mathrm{Hg}$ mine. However, concentrations of methyl-Hg in soil and water in this study were generally found to be low. The study area is in the Chihuahuan Desert, a dry and highly oxidized environment, where methyl-Hg formation is generally low.

Acknowledgements This study was funded by the U.S. Geological Survey (USGS, Mineral Resources Program). We thank John DeWild (USGS, Middleton, Wisconsin) for $\mathrm{Hg}$ analysis of air and soil gas samples and Brenda Lasorsa (Battelle Marine Sciences Laboratory, Sequim, Washington) for providing $\mathrm{Hg}$ and methyl-Hg analyses on soil and water samples. We thank Geoff Plumlee (USGS) and anonymous reviewers for Environmental Geochemistry and Health for constructive comments that helped to improve this paper. Greg Lee (USGS) assisted with graphics and Karl Ellefsen (USGS) helped with statistical calculations. Any use of trade, product, or firm names is for descriptive purposes only and does not imply endorsement by the U.S. Government.

Open Access This article is distributed under the terms of the Creative Commons Attribution License which permits any use, distribution, and reproduction in any medium, provided the original author(s) and the source are credited. 


\section{References}

Alpers, C. N., Fleck, J. A., Marvin-DiPasquale, M., Stricker, C. A., Stephenson, M., \& Taylor, H. E. (2013). Mercury cycling in agricultural and managed wetlands, Yolo Bypass, California: Spatial and seasonal variations in water quality. Science of the Total Environment, 484, 276-287.

ATSDR (2012). Action levels for elemental mercury spills. Agency for Toxic Substances and Disease Registry, http:// www.atsdr.cdc.gov/emergency_response/Action_Levels_ for_Elemental_Mercury_Spills_2012.pdf, Accessed 11 July 2013.

Avery, D. W., Moyle, P. R., Reisenburg, R. M., \& Fay, J. M. (1996). Preliminary assessment and site inspection, the Mariscal mine and mill site, Big Bend National Park, Brewster County. Texas: U.S. Bureau of Mines, Site Characterization Section.

Bailey, E. A., Gray, J. E., \& Theodorakos, P. M. (2002). Mercury in vegetation and soils at abandoned mercury mines in southwestern Alaska, USA. Geochemistry: Exploration, Environment, Analysis, 2(3), 275-285.

Berndt, M. E., \& Bavin, T. K. (2012). Methylmercury and dissolved organic carbon relationships in a wetland-rich watershed impacted by elevated sulfate from mining. Environmental Pollution, 161, 321-327.

Bloom, N. S., Colman, J. A., \& Barber, L. (1997). Artifact formation of methyl mercury during aqueous distillation and alternative techniques for the extraction of methyl mercury from environmental samples. Fresenius Journal of Analytical Chemistry, 358, 371-377.

Compeau, G. C., \& Bartha, R. (1985). Sulfate-reducing bacteria: Principal methylators of mercury in anoxic estuarine sediment. Applied and Environment Microbiology, 50, 498-502.

Eckley, C. S., Gustin, M., Lin, C. J., Li, X., \& Miller, M. B. (2010). The influence of dynamic chamber design and operating parameters on calculated surface-to-air mercury fluxes. Atmospheric Environment, 44, 194-203.

Eisler, R. (1987). Mercury hazards to fish, wildlife, and invertebrates: A synoptic review. (pp. 90): U.S. Fish and Wildlife Service, Biological Report 85(1.10).

Engle, M. A., Gustin, M. S., \& Zhang, H. (2001). Quantifying natural source mercury emissions from the Ivanhoe Mining District, north-central Nevada, USA. Atmospheric Environment, 35, 3987-3997.

Ferrara, R., Maserti, B. E., Andersson, M., Edner, H., Ragnarson, P., Svanberg, S., et al. (1998a). Atmospheric mercury concentrations and fluxes in the Almadén district (Spain). Atmospheric Environment, 32(22), 3897-3904.

Ferrara, R., Maserti, B. E., \& Breder, R. (1991). Mercury in abiotic and biotic compartments of an area affected by a geochemical anomaly (Mt. Amiata, Italy). Water, Air, and Soil pollution, 56, 219-233.

Ferrara, R., Mazzolai, U. B., Edner, H., Svanberg, S., \& Wallinder, E. (1998b). Atmospheric mercury sources in the Mt. Amiata area Italy. Science of the Total Environment, 213, 12-23.

Fitzgerald, W. F. (1986). Cycling of mercury between the atmosphere and oceans. In P. Buat-Menard (Ed.), NATO ASI Series. Series C: Mathematical and Physical Sciences, vol.185 (pp. 363-408).
Fitzgerald, W. F., \& Clarkson, T. W. (1991). Mercury and monomethylmercury: Present and future concerns. Environmental Health Perspectives, 96, 159-166.

Fitzgerald, W. F., Engstrom, D. R., Mason, R. P., \& Nater, E. A. (1998). The case for atmospheric mercury contamination in remote areas. Critical Reviews Environmental Science and Technology, 32(1), 1-7.

Gabriel, M. C., Williamson, D. G., Brooks, S., Zhang, H., \& Lindberg, S. (2005). Spatial variability of mercury emissions from soils in a southeastern US urban environment. Environmental Geology, 48, 955-964.

García-Sánchez, A., Contreras, F., Adams, M., \& Santos, F. (2006). Atmospheric mercury emissions from polluted gold mining areas (Venezuela). Environmental Geochemistry and Health, 28, 529-540.

Gosar, M., Pirc, S., \& Bidovec, M. (1997). Mercury in the Idrijca river sediments as a reflection of mining and smelting activities of the Idrija mercury mine. Journal of Geochemical Exploration, 58, 125-131.

Gray, J. E., Crock, J. G., \& Lasorsa, B. K. (2002). Mercury methylation at mercury mines in the Humboldt River Basin, Nevada (pp. 143-149). Environment, Analysis: USA. Geochemistry Exploration.

Gray, J. E., \& Hines, M. E. (2006). Mercury: Distribution, transport, and geochemical and microbial transformations from natural and anthropogenic sources. Applied Geochemistry, 21(11), 1819-1820. doi:10.1016/j.apgeochem. 2006.09.001.

Gray, J. E., Hines, M. E., \& Biester, H. (2006). Mercury methylation influenced by areas of past mercury mining in the Terlingua district, Southwest Texas, USA. Applied Geochemistry, 21, 1940-1954.

Gray, J. E., Hines, M. E., Higueras, P. L., Adatto, I., \& Lasorsa, B. K. (2004). Mercury speciation and microbial transformations in mine wastes, stream sediments, and surface waters at the Almadén mining district Spain. Environmental Science and Technology, 38(16), 4285-4292.

Gray, J. E., Plumlee, G. S., Morman, S. A., Higueras, P. L., Crock, J. G., Lowers, H. A., et al. (2010). In vitro studies evaluating leaching of mercury from mine waste calcine using simulated human body fluids. Environmental Science and Technology, 44, 4782-4788.

Gray, J. E., Theodorakos, P. M., \& Krabbenhoft, D. P. (2008). Evaluation of mercury contamination at inactive mercury mines in and around Big Bend National Park. (pp. 57-64): U.S. Geological Survey Circular 1327.

Higueras, P., Esbrí, J. M., Oyarzun, R., Llanos, W., MartínezCoronado, A., Lillo, J., et al. (2013). Industrial and natural sources of gaseous elemental mercury in the Almadén district (Spain): An updated report on this issue after the ceasing of mining and metallurgical activities in 2003 and major land reclamation works. Environmental Research, 125, 197-208.

Higueras, P., Llanos, W., García, M. E., Millán, R., \& Serrano, C. (2012). Mercury vapor emissions from the Ingenios in Potosí (Bolivia). Journal of Geochemical Exploration, 116, 1-7.

Higueras, P., Oyarzun, R., Kotnik, J., Esbrí, J. M., MartínezCoronado, A., Horvat, M., et al. (2014). A compilation of field surveys on gaseous elemental mercury (GEM) from contrasting environmental settings in Europe, South 
America South Africa and China: Separating fads from facts. Environmental Geochemistry and Health, doi:10. 1007/s10653-013-9591-2.

Hines, M. E., Horvat, M., Faganeli, J., Bonzongo, J. J., Barkay, T., Major, E. B., et al. (2000). Mercury biogeochemistry in the Idrija River, Slovenia, from above the mine into the gulf of Trieste. Environmental Research Section A, 83, 129-139.

Hudson, R. J. M., Gherini, S. A., Fitzgerald, W. F., \& Porcella, D. B. (1995). Anthropogenic influences on the global mercury cycle: A model-based analysis. Water, Air, and Soil pollution, 80, 265-272.

Kennedy, K. R., \& Crock, J. G. (1987). Determination of mercury in geological materials by continuous-flow, coldvapor, atomic absorption spectrophotometry. Analytical Letters, 20, 899-908.

Kim, C. S., Bloom, N. S., Rytuba, J. J., \& Brown, G. E, Jr. (2003). Mercury speciation by X-ray absorption fine structure spectroscopy and sequential chemical extractions: A comparison of speciation methods. Environmental Science and Technology, 37(22), 5102-5108.

Kocman, D., Horvat, M., Pirrone, N., \& Cinnirella, S. (2013). Contribution of contaminated sites to the global mercury budget. Environmental Research, 125, 160-170.

Lamborg, C. H., Fitzgerald, W. F., O'Donnell, J., \& Torgersen, T. (2002). A non-steady-state compartmental model of global-scale mercury biogeochemistry with interhemispheric atmospheric gradients. Geochimica et Cosmochimica Acta, 66, 1105-1118.

MacDonald, D. D., Ingersoll, C. G., \& Berger, T. A. (2000). Development and evaluation of consensus-based sediment quality guidelines for freshwater ecosystems. Archives of Environment Contamination and Toxicology, 39, 20-31.

Mason, R. P., Fitzgerald, W. F., \& Morel, F. M. M. (1994). The biogeochemical cycling of elemental mercury: Anthropogenic influences. Geochimica et Cosmochimica Acta, 58(15), 3191-3198.

NAS. (1978). An assessment of mercury in the environment. Washington, D.C.: National Academy of Sciences, National Research Council.

Nriagu, J. O., \& Pacyna, J. M. (1988). Quantitative assessment of worldwide contamination of air, water and soils by trace metals. Nature, 333, 134-139.

Porcella, D. B. (1994). Mercury in the environment: Biogeochemistry. In C. J. Watras \& J. W. Huckabee (Eds.), Mercury pollution (pp. 3-19). Boca Raton: CRC Press.

Qiu, G., Feng, X., Wang, S., \& Shang, L. (2005). Mercury and methylmercury in riparian soil, sediments, mine-waste calcines, and moss from abandoned $\mathrm{Hg}$ mines in east Guizhou province, southwestern China. Applied Geochemistry, 20, 627-638.

Rimondi, V., Gray, J. E., Costagliola, P., Vaselli, O., \& Lattanzi, P. (2012). Concentration, distribution, and translocation of mercury and methylmercury in mine-waste, sediment, soil, water, and fish collected near the Abbadia San Salvatore mercury mine, Monte Amiata district, Italy. Science of the Total Environment, 414, 318-327.

Ross, C. P. (1941). The quicksilver deposits of the Terlingua region, Texas. Economic Geology, 35, 115-142.

Sharp, R. D. (1980). Development of the mercury mining industry Trans-Pecos Texas. Mineral Resource Circular: Texas Bureau of Economic Geology. 64.
Tomiyasu, T., Matsuyama, A., Imura, R., Kodamatani, H., Miyamoto, J., Kono, Y., et al. (2012). The distribution of total and methylmercury concentrations in soils near the Idrija mercury mine, Slovenia, and the dependence of the mercury concentrations on the chemical composition and organic carbon levels of the soil. Environmental Earth Science, 65, 1309-1322.

Ullrich, S. M., Tanton, T. W., \& Abdrashitova, S. A. (2001). Mercury in the aquatic environment: A review of factors affecting methylation. Critical Reviews in Environmental Science and Technology, 31, 241-293.

USEPA (1994). Test methods for evaluating solid waste: Method 1312, Synthetic precipitation leaching procedure. Revision O, U.S. Environmental Protection Agency. http:// www.epa.gov/osw/hazard/testmethods/sw846/pdfs/1312. pdf, Accessed 16 Sept 2013.

USEPA (1995). National recommended water quality criteria, United States environmental protection agency, http:/www. epa.gov/ost/criteria/wqctable/, Accessed 11 June 2013.

USEPA (1997). Mercury study report to congress. U.S. environmental protection agency, I-VIII, EPA-452/R-97-003.

USEPA (1998). Method 1630: Methyl mercury in water by distillation, aqueous ethylation, purge and trap, and cold vapor atomic fluorescence method spectrometry, U.S. Environmental Protection Agency, Office of Water, $401 \mathrm{M}$ Street SW, Washington, D.C. 20460. (pp. 46).

USEPA (2001). Total mercury in tissue, sludge, sediment, and soil by acid digestion and $\mathrm{BrCl}$ oxidation. U.S. Environmental Protection Agency, EPA-821-R-01-013.

USEPA (2002). Method 1631, Revision E: Mercury in water by oxidation, purge and trap, and cold vapor atomic fluorescence spectrometry. U.S. Environmental Protection Agency, EPA 821-R-02-019.

USEPA (2009). Water: Drinking water contaminants, United States environmental protection agency, EPA 816-F-09-0004, http:// water.epa.gov/drink/contaminants/index.cfm\#two, Accessed 11 June 2013.

USEPA (2013). Human health medium specific screening levels. U.S. Environmental Protection Agency, http://www. epa.gov/region6/6pd/rcra_c/pd-n/screen.htm, Accessed 11 May 2013.

Walvoord, M. A., Andraski, B. J., Krabbenhoft, D. P., \& Striegl, R. G. (2008). Transport of elemental mercury in the unsaturated zone from a waste disposal site in an arid region. Applied Geochemistry, 23, 572-583.

Wang, S., Feng, X., Qiu, G., Wei, Z., \& Xiao, T. (2005). Mercury emission to atmosphere from Lanmuchang $\mathrm{Hg}-\mathrm{Tl}$ mining area, Southwestern Guizhou, China. Atmospheric Environment, 39, 7459-7473.

WHO (1976). Environmental health criteria. Vol.1. Mercury. Geneva, Switzerland: World Health Organization.

WHO. (1990). Methylmercury, environmental health criteria 101. Geneva: World Health Organization.

WHO (2000). Air quality guidelines for Europe. WHO Regional Publications European Series 91. (pp. 288): World Health Organization, Regional Office for Europe, Copenhagen.

WHO (2005). Mercury in Drinking-water. (Vol. WHO/SDE/ WSH/05.08/10): World Health Organization. 